\title{
Marketing Analysis of Vegetables: The Case of Carrot and Cucumber Marketing in Enugu State, Nigeria
}

\author{
Ridwan Mukaila ${ }^{1, a}$, Angela Ebere Obetta ${ }^{1, b, *}$, Festus EluwandeDurojaye Awoyelu ${ }^{1, c}$, Chinedum Jachinma \\ Chiemela $^{1, d}$, Anthony Onyedika Ugwu ${ }^{1, e}$
}

${ }^{I}$ Department of Agricultural Economics, University of Nigeria, Nsukka, Enugu State, Nigeria *Corresponding author

\begin{tabular}{|c|c|}
\hline A R T I C L E I N F O & A B S T R A C T \\
\hline $\begin{array}{l}\text { Keywords: } \\
\text { Challenges } \\
\text { Marketing margin } \\
\text { Retailers } \\
\text { Vegetable marketing } \\
\text { Wholesalers }\end{array}$ & $\begin{array}{l}\text { Agricultural marketing plays a vital role in economic development and livelihood of people in } \\
\text { developing countries. Marketing of agricultural products which provide income to most farmers } \\
\text { and marketers in Nigeria has been characterised with a lot of deficiencies which have constrained } \\
\text { sustainable development and economic growth. This study, therefore, analysed carrot and cucumber } \\
\text { marketing including constraints to their effective marketing in Enugu State, Nigeria. Data collected, } \\
\text { primarily, were analysed using descriptive statistics, marketing margin and Likert type rating } \\
\text { technique. The result shows that vegetable marketing was dominated by females (65\%) who were } \\
\text { still in their economically active age and did not belong to a cooperative society. Half of them } \\
\text { perform a retail marketing function, } 30 \% \text { perform both retail and wholesale functions while } 20 \% \\
\text { perform wholesale function. Vegetable marketing contributed to marketers' income by providing } \\
\text { N25,667.7 (USD 66.93) per month on average. The marketing margins were } 26.30 \% \text { and } 20.18 \% \\
\text { for cucumber and carrot, respectively. The high cost of shop rent, high transportation cost, low } \\
\text { capital, price fluctuation, poor credit facilities and a low supply of vegetables due to seasonal } \\
\text { variation were the major constraints faced by vegetable marketers. Vegetable marketers, therefore, } \\
\text { need support by providing affordable credit facilities and building of modern market stalls by the } \\
\text { government. This would give them a conducive and hygienic environment. Also, vegetable } \\
\text { marketers should form a cooperative society where they can pool resources and get financial } \\
\text { assistance. This would lead to efficient marketing of the product. }\end{array}$ \\
\hline
\end{tabular}

ridwan.mukaila@unn.edu.ng festus.awoyelu@unn.edu.ng b.jibson@gmail.com

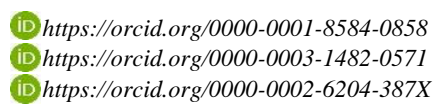

(iD) https://orcid.org/0000-0001-8584-0858 iD https://orcid.org/0000-0003-1482-0571 (iD) https://orcid.org/0000-0002-6204-387X

https://orcid.org/0000-0002-0562-2648 https://orcid.org/0000-0002-8605-0871

\section{Introduction}

One of the key important factors for sustainable development and economic growth in any nation is marketing. Efficient marketing system in the agricultural sector, especially among smallholder marketers in developing nations, plays a vital role in economic development (Xaba and Masuku, 2012; Botlhoko and Oladele, 2013). Yet policy emphasis is usually placed on increasing the level of agricultural production for rural development in most developing nations which depends on agriculture for its economy (Yohanes, 2015). Increasing agricultural production may experience several setbacks if the market is not functioning well. The poor marketing system is the major cause of price fluctuation which posed a risk to the farmers and will force them to sell at any available price because of the perishable nature of the produce. Understanding marketing system and its constraints become necessary to improve the marketing system.
Marketing provides form, possession, place and time utility to commodity and services thereby has economic value (Asogwa and Okwoche, 2012). Agricultural marketing deal with the movement of commodities from the farm gate to the consumption centre and include all the activities involved in the value chain. The middlemen (marketers or marketing agents) usually perform most of the marketing functions as farmer/producer may not perform the marketing function effectively (Arene, 2003). The marketing agents/middle men thus play a significant role in distributing products to consumers located within or outside a region. Within the marketing channel, the actors are the wholesalers and retailers. Intermediaries are involved essentially in financing, disseminating of market information, physical movement and storage of goods. The middlemen, therefore, overcome the possession, place and time gap that separate commodities from those that want 
them (Kotler and Keller 2012). In a competitive market, it is expected that the marketing agents will charge the minimum price which will cover the cost and give a normal profit. The major determinants of returns to marketers is the marketing margin which is the difference between what the producer receives and what the consumer pays. This must be enough to cover the cost of marketing without which the morale to continue production is dammed.

The role of vegetable crops cannot be overemphasised in Nigeria and other sub-Sahara Africa countries. It plays a significant role in income generation, improving nutritional and food security status of people, serves as means of livelihood to several households, especially rural dwellers who engaged in its production activities and urban areas where most of the products are being marketed. Vegetable production such as carrot and cucumber require a small area of land, unlike other crops which require a large area of land. Vegetables thereby give a higher number of employments per hectare of land, off-farm and on-farm enterprise (Ali et al., 2002). Vegetables are nutritionally important to man as they provide the much-needed vitamins, minerals and fibres essential for a healthy life and prevention of diseases. Carrot and cucumber are highly nutritious, rich in minerals and vitamin A, safe and healthy for consumption. Vegetables must, therefore, be always available at the required quality and quantity. Also, the price should be stable, be within consumers' range and safe for consumption (Firdaus and Gunawan, 2012).

As Nigeria is diversifying her economy into the agricultural sector, vegetable production and its marketing are of great importance as it will not only increase farmers and marketer's income but also generate revenue to the government and improve the wellbeing of its producers and other people involved in its value chain. Despite the importance and potentials of vegetable marketing in alleviating poverty, improving nutritional and food security status of people both in rural and urban areas, little has been done on it in Enugu State Nigeria. To design appropriate policies that will bring about efficient marketing of vegetables (carrot and cucumber), there is a need to carry out an indebt study of vegetable marketing. This study, therefore, analysed the marketing of carrot and cucumber in Enugu East Local Government Area of Enugu state. Specifically, the study identified the socio-economic characteristics of carrot and cucumber marketers; described the marketing channels of carrot and cucumber; determined the marketing margins of the vegetable marketing; and identify the marketing function performed by carrot and cucumber marketers. The constraints faced in marketing vegetables were also investigated in this study as this would benefit producers, marketers and help policymakers to identify the areas to channel policy formulation to improve vegetable marketing.

\section{Materials and Methods}

\section{Study Area}

This study was conducted in Enugu East Local Government Area (LGA) of Enugu State, Nigeria. Enugu East LGA has an area of $383 \mathrm{~km}^{2}$ and has a population of about 279,089 people. It lies between latitude $7^{\circ} 39^{\prime} \mathrm{N}$ and longitude $7^{\circ} 41^{\prime} \mathrm{E}$ at an altitude of $202 \mathrm{~m}$ (NPC, 2006; ENADEP, 2012). There are major markets in Enugu East
LGA: Orie Emene, Orie Ogwogo Nike, Nkwo Nike market, Abakpa main market, Afor Ibagwa, Eke Nkubo, Eke Obinagu, Afor Ugwoma and Trans-Ekulu market. Agriculture is one of the major occupations of the people in this area, especially the rural areas. They are smallholder farmers and marketers of several agricultural products such as rice, maize, yam, cassava, carrot, cucumber, cocoyam, pepper, groundnut, watermelon, banana and plantain among others.

\section{Sampling Procedure and Data Collection}

The study adopted a survey design. Random and purposive sampling techniques were used to select respondents for this study. Three communities were firstly purposively selected from Enugu East LGA based on the size of the market presence in each of them. The communities involved were: Abakpa Nike, Ogwogo Nike and Emene Nike. In the second stage, two markets were purposively selected from each community because of the high vegetable marketers present there. The markets selected were: Afor Ibagwa, Abakpa main market, Eke Obinagu, Trans-Ekulu market, Orie Ogwogo market and Orie Emene market. Lastly, ten marketers were randomly selected from each of the six markets giving a total of sixty respondents for this study. The data were primarily collected using structured questionnaire administered to carrot and cucumber marketers and oral interview. The questionnaires were administered by the researchers and were used to collect data on the socio-economic characteristics of the vegetable marketers, marketing channel, the marketing margin and various carrot and cucumber marketing constraints.

\section{Data Analysis}

Descriptive statistics such as mean, frequencies, percentages and tables were used to describe the socioeconomic characteristics of carrot and cucumber marketers, identified the marketing channels of carrot and cucumber and identify the marketing function performed by carrot and cucumber marketers.

Marketing margin analysis was used to determine the marketing margins of vegetable marketing. Marketing margin is widely used in agricultural marketing research e.g., Fadipe et al. (2015); Dinesh and Sharma (2019). Marketing margin for vegetable marketing amongst vegetable marketers refers to the difference between the consumer price and the price paid by the vegetable marketers to the producers.

$$
\mathrm{MM}=\frac{\mathrm{SP}-\mathrm{PP}}{\mathrm{SP}} \times \frac{100}{1}
$$

Where;

$$
\begin{aligned}
& \mathrm{MM}=\text { Marketing margin } \\
& \mathrm{SP}=\text { Selling price } \\
& \mathrm{PP}=\text { Producers' price }
\end{aligned}
$$

A 4-point Likert type rating technique was used to identify the various constraints of carrot and cucumber marketing. The questions and their corresponding points were as follows, extreme severe (4), very severe (3), severe (2) not severe (1). The real limit point was calculated by 
adding the scale points and dividing by the number of scales. This was calculated as follow, $4+3+2+1 / 4$. This gave a limit value of 2.5 showing that any constraints of the vegetable marketers with a score less than $2.5(<2.5)$ does not seriously affect the marketing of vegetables (carrot and cucumber), but any constraints with the score greater than or equal to 2.5 $(\geq 2.5$ ) seriously affect the marketing of carrot and cucumber.

\section{Results and Discussion}

\section{Socio-Economic Characteristics of the Vegetable Marketers}

The socioeconomic characteristics of vegetable marketers are presented in Table 1 . The age distribution of the respondents is important in the socioeconomic study because it gives an idea on experience and ability to diversify into different activities which could increase performance and efficiency of marketing. The majority of the vegetable marketers were below 40 years, $35 \%$ were within 41 to 50 years while only $3.3 \%$ were above 50 years. The mean age of the marketers was 37.53 years. This suggests that the youths in the area are engaged in the marketing of these agricultural products. This implies that the carrot and cucumber marketers were within their economically active age when they are likely to perform the marketing functions effectively. Marketing of vegetables in Nigeria involved going to the farms which are situated in rural areas regularly by the marketers to purchase fresh vegetables from the farmers. This required energy and physical fitness; thus, younger marketers possessed the required energy for this function and are likely to contribute positively to vegetable marketing than their older counterpart. Younger agricultural marketers are more dynamics, willing to take risks associated with marketing and perform marketing functions with youthful vigour (Obetta et al., 2020). The gender distribution of the respondents gives an idea of sex differentials and its marketing implications. The majority $(65 \%)$ of the vegetable's marketers were females (Table 1$)$. It indicates that females are mostly found in marketing this agricultural produce. This could be because the business is not as tedious as other agricultural marketing business.

Regarding their educational status, the majority $(56.7 \%)$ of the vegetable marketers had secondary education, $26.7 \%$ had primary school education while only $16.7 \%$ had no formal education. This indicates that vegetable marketing in the study area require a certain level of education in terms of management to ensure not just productivity but enhanced marketing functions. The majority $(60 \%)$ of the vegetable marketers were married, $28.3 \%$ and $11.7 \%$ were single and divorced, respectively. The proportion of married marketers correspond with their age groups as about 70 percent of the marketers were above 30 years. The high proportion of married respondents suggests that they have dependants, some of whom may be involved in the business as well. This could be because marketers require support from their spouse while children could serve as a family source of labour in the business. This further suggests that married people were more involved in vegetable marketing in the study area than single individuals.

Table 1: Socio-economic characteristics of vegetable marketers. Source: Field survey, 2019.

\begin{tabular}{|c|c|c|c|c|}
\hline Variables & Categories & Frequency & Percentage & Mean \\
\hline \multirow{4}{*}{ Age } & $\leq 30$ & 19 & 31.7 & \multirow{4}{*}{37.53} \\
\hline & $31-40$ & 18 & 30 & \\
\hline & $41-50$ & 21 & 35 & \\
\hline & $51-60$ & 2 & 3.3 & \\
\hline \multirow{2}{*}{ Gender } & Male & 21 & 35 & \\
\hline & Female & 39 & 65 & \\
\hline \multirow{3}{*}{ Educational level } & No formal education & 10 & 16.7 & \\
\hline & Primary school level & 16 & 26.7 & \\
\hline & Secondary school level & 34 & 56.7 & \\
\hline \multirow{3}{*}{ Marital status } & Married & 36 & 60 & \\
\hline & Single & 17 & 28.3 & \\
\hline & Divorced & 7 & 11.7 & \\
\hline \multirow{2}{*}{ Primary occupation } & Farming & 4 & 6.7 & \\
\hline & Marketing & 56 & 93.3 & \\
\hline \multirow{3}{*}{ Years of experience } & $2-5$ & 28 & 46.7 & \multirow{3}{*}{5.82} \\
\hline & $6-10$ & 31 & 51.7 & \\
\hline & $11-15$ & 1 & 1.7 & \\
\hline \multirow{2}{*}{ Source of fund } & Personal fund & 58 & 96.7 & \\
\hline & Relatives \& friends & 2 & 3.3 & \\
\hline \multirow{3}{*}{ Business size } & $1-2$ & 56 & 93.3 & \multirow{3}{*}{1.27} \\
\hline & $3-4$ & 3 & 5 & \\
\hline & 5 and above & 1 & 1.7 & \\
\hline \multirow{2}{*}{ Cooperative membership } & Member & 0 & 0 & \\
\hline & Non-member & 60 & 100 & \\
\hline \multirow{2}{*}{ Access to credit } & Get access & 0 & 0 & \\
\hline & No access & 60 & 100 & \\
\hline \multirow{4}{*}{ Monthly income $(\mathrm{N})$} & $<20,000$ & 19 & 31.7 & \multirow{4}{*}{$25,667.7(\$ 66.93)$} \\
\hline & $20,001-30,000$ & 21 & 35 & \\
\hline & $30,001-40,000$ & 17 & 28.3 & \\
\hline & $>40,001$ & 3 & 5 & \\
\hline
\end{tabular}


Table 2. Marketing functions performed by vegetable marketers and source of vegetables

\begin{tabular}{c|ccc}
\hline Variables & Categories & Frequency & Percentage (\%) \\
\hline \multirow{2}{*}{ Marketing function } & Retail only & 30 & 50 \\
& Both wholesale and retail & 18 & 30 \\
& Wholesale only & 12 & 20 \\
\hline \multirow{2}{*}{ Source of vegetables } & Bought within the state & 36 & 60 \\
& Bought outside the state & 24 & 40 \\
\hline
\end{tabular}

Source: Field survey, 2019.

Table 3. Marketing margin of vegetables

\begin{tabular}{l|ccc}
\hline \multirow{2}{*}{ Vegetables } & \multicolumn{3}{c}{ Marketing margin } \\
\cline { 2 - 4 } & Wholesalers & Retailers & Total \\
\hline Cucumber & $11.76 \%$ & $14.54 \%$ & $26.30 \%$ \\
Carrot & $9.04 \%$ & $11.14 \%$ & $20.18 \%$ \\
Both & $20.80 \%$ & $25.68 \%$ & $46.48 \%$ \\
\hline
\end{tabular}

Source: Field survey, 2019.

Table 4. Constraints militating against effective marketing of vegetables

\begin{tabular}{l|ccccc}
\hline S/N & Constraints & Mean & Std. dev. & Decision & Rank \\
\hline 1 & High cost of shop rent & 3.13 & 0.623 & Accept & $1^{\text {st }}$ \\
2 & High cost of transportation & 3.00 & 0.902 & Accept & $2^{\text {nd }}$ \\
3 & Low capital/Initial Investment & 2.95 & 1.096 & Accept & $3^{\text {rd }}$ \\
4 & Price fluctuation & 2.93 & 0.710 & Accept & $4^{\text {th }}$ \\
5 & Lack of financial support (credit facilities) & 2.90 & 1.020 & Accept & $5^{\text {th }}$ \\
6 & Low supply of vegetables due to seasonal variation & 2.63 & 1.008 & Accept & $6^{\text {th }}$ \\
7 & Poor storage facilities & 1.95 & 0.852 & Reject & $7^{\text {th }}$ \\
8 & Inadequate Information & 1.92 & 0.743 & Reject & $8^{\text {th }}$ \\
9 & Rapid deterioration in quality & 1.63 & 0.688 & Reject & $9^{\text {th }}$ \\
10 & Heavy Imposition of tax & 1.58 & 0.671 & Reject & $10^{\text {th }}$ \\
\hline
\end{tabular}

Source: Field survey, 2019.

Married people are usually involved in such businesses possibly because of the need to supplement family means of livelihood. Investigating the occupation distribution of the respondents is important because having a business as one's primary occupation possibly accelerates better management somewhat different from other marketers who may have diversified businesses and as such diversify income and interest in vegetable marketing. Table 1 shows that the majority of the marketers $(93.3 \%)$ engage in the vegetable marketing business as their core occupation. Taking vegetable marketing as their primary occupation gives the vegetable marketers a better sense of direction, a sense of focus and a better sense of managing the business as they put all their attention and resources towards the venture. More than half $(51.67 \%)$ of the vegetable marketers had between 6 and 10 years of experience in the business, $46.7 \%$ of them had between 2 and 5 years while only $1.7 \%$ had between 11 - and 15-years vegetable marketing experience. The mean years of marketing experience was 5.82 years. This suggests that the marketers are well established and knowledgeable in marketing of the vegetable product. The longer a marketer spends in marketing business activities, the better the marketer understands the business atmosphere, market price fluctuations, consumer behaviours and rudiments in the distribution sector. Regarding the source of fund used in their business, the majority of the marketers sourced their fund from personal savings, while only 3.3\% got theirs from relatives and friends.

Examining the vegetable marketers' business size is important because while the number of employees can enhance the vegetable marketing business potentials, it may just be possible when the business is in good economic standing but if reverse is the case, the business would be faced with more tough decisions to either cut labour to maintain cash inflows or retain labour in the business. Also, while the number of employees can depict business growth or expansion, it is subject to a constant rate of returns. The majority (93.3\%) of the vegetable marketers employed between 1 and 2 employees (Table 1). This is an indication that vegetable marketing business enterprises employed a few numbers of staff and are basically operating on a small scale since a greater percentage of them employed less than 3 persons. Regarding access to credit, all the marketers do not have access to credit. Similarly, they are not a member of any cooperative society. This could be the reason behind the low investment in the business as they neither borrow from cooperatives nor commercial institutions. But on the other hand, problems of loan repayment and interest rate were avoided. The vegetable marketers had a mean monthly income of N25,667.7 (USD 66.93). This possibly could be attributed to the commercial status of the study area with high demand for vegetable product or market availability and suitable pricing of vegetable produce. The monthly income gives the proxy that the vegetable marketing business was profitable and contributed to household welfare.

\section{Marketing Channels of Vegetables Marketers}

In this context, marketing channel referred to the various means by which carrot and cucumber moves from the producers to the consumers. 
Four vegetable marketing channels were identified. They are:
A: Producers $\rightarrow$ Consumers
$\mathrm{B}:$ Producers $\rightarrow$ Wholesalers $\rightarrow$ Consumers
$\mathrm{C}:$ Producers $\rightarrow$ Retailers $\rightarrow$ Consumers
D: Producers $\rightarrow$ Wholesalers $\rightarrow$ Retailers $\rightarrow$ Consumers

Figure 1 further presents the marketing channel of vegetables in the study area. The directions of the marketing channels of vegetable are not specific as it follows a different path. Some retailers bypassed the wholesalers to get to the producer, this route is common in cucumber marketing. Also, some consumer bypassed the retailers and buy from the wholesalers. The bypassing was aimed at buying at a low price and to buy vegetables in fresh conditions. Marketing channel A was found in the marketing of cucumber because it was widely produced by farmers within the state and few consumers get their cucumber directly from the producers. Marketing channel $\mathrm{D}$ was the major channel found in the study area. In this channel D, after harvesting of carrot and cucumber, the wholesalers purchased them from the producers and distributes to the retailers in the markets. The final consumers bought their vegetables from the retailers (Figure 1).

\section{Marketing Functions Performed by Vegetable Marketers and Source of Vegetables}

Table 2 presents the marketing functions performed by vegetable marketers and the source of vegetables sold in the study area. There were different marketing functions in which the vegetables (carrot and cucumber) marketers performed in the study area. The marketers who performed only retails function were half of the marketers, thus are retailers (Table 2). The functions they performed include cleaning of the vegetables and packaging of the produce. There were marketers who performed both retail and wholesales' (30\%) function in the study area. Only 20 percent of the marketers performed solely wholesales function. They were involved in assembling and distribution of vegetables from the farmers to the retailers. Some of the vegetable wholesalers also sort the vegetables before selling to the retailers.

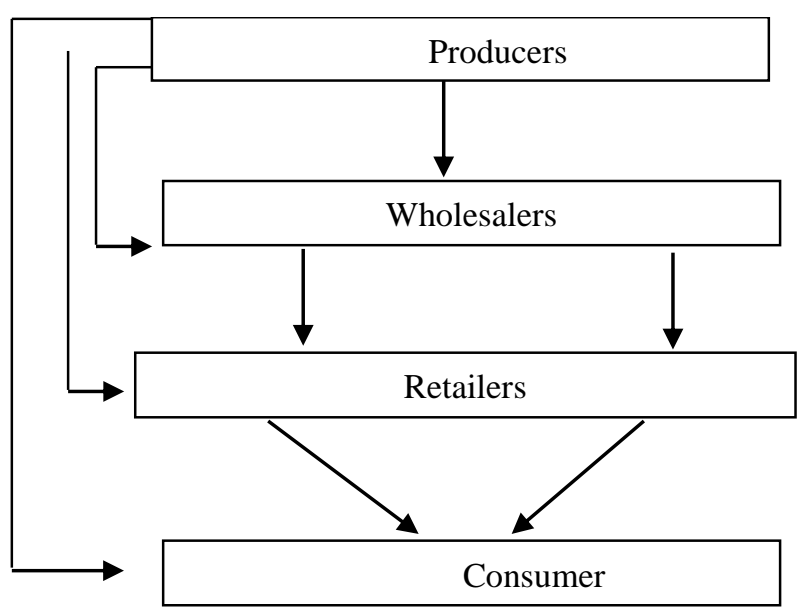

Figure 1. Marketing channels of carrot and cucumber Source: Field survey, 2019.
Regarding source of vegetables, the majority $(60 \%)$ of the marketers purchase their vegetable produce from the farmers within the state. While $40 \%$ of them purchase vegetables, especially carrot, from other farms in the Northern part of the country (Table 2). This suggests that the cost of transportation will be high as they travel a long distance to make their purchase. The retailers of these products in the study area do not depend only on farmers within the state that produce in small quantity but also depend on wholesalers that usually buy the produce from the Northern part of Nigeria, mostly from Jos. This is one of the reasons why vegetables (carrot and cucumber) can be seen in every market in the area.

\section{Marketing Margin of Vegetable Marketers}

The marketing margin of carrot and cucumber marketers which shows the share of marketers in consumers' price is shown in Table 3. The result shows that vegetable wholesalers had an average marketing margin of $11.76 \%$ and $9.04 \%$ for cucumber and carrot, respectively. This implies that the wholesalers had $11.76 \%$ and $9.04 \%$ share of consumer's price of cucumber and carrot, respectively. The share of the retailers in consumer's price was $14.54 \%$ and $11.14 \%$ for cucumber and carrot, respectively. In total, the marketers share of the consumers' price was $26.30 \%$ and $20.18 \%$ for cucumber and carrot, respectively. This suggests that vegetable marketing was viable and the venture was profitable. Furthermore, the level of marketing margin was higher in cucumber than carrot. The higher marketing margin accrued to cucumber was as a result of low transportation cost because most of the cucumber sold in the study area were sourced within the state. While carrot had a lower marketing margin because of the high transportation cost accrued to its distribution from the northern part of the country to the study area.

\section{Constraints Militating Against Effective Marketing of Vegetables}

The constraints faced in marketing of vegetables among carrot and cucumber marketers are presented in Table 4 . The result revealed that vegetable enterprise was bedevilled by many critical problems. The results showed that high cost of shop rent, high cost of transportation, low capital, price fluctuation, finance and a low supply of vegetables due to seasonal variation were the major and severe constraints faced by all the marketers in the study area. While poor storage facilities, inadequate information, rapid deterioration in quality and heavy imposition of tax were not severe problems militating against effective vegetable marketing.

The high cost of shop rent was ranked first among the major problems. This could be attributed to the high number of vegetable marketers in the market which may lead to the competition of shops or space and limited space for the vegetable marketers in the study area. The high cost of transportation was also a major constraint militating against effective marketing of carrot and cucumber. This result is in coherent with Senyolo et al., (2009); Matsane and Oyekale (2014) and Obetta et al. (2020) who reported that poor infrastructures such as road lead to poor marketing functions in domestic markets. This may be accompanied by bad roads and long-distance involved in moving the product from point of purchase to the point of sales. Low capital was ranked third among the constraints, this may be attributed to lack of 
access to credit facilities among the vegetable marketers. Another severe constraint was price fluctuation due to lack of mechanism to regulate agricultural products' prices. This is common to agricultural products which are seasonal and perishable in nature. This is attributed to poor storage facilities to store vegetables. A similar result was reported by Matsane and Oyekale (2014) that poor pricing and lack of storage facilities were among the severe constraints faced in vegetable marketing. Lack of financial support was also a serious problem. This is also attributed to the fact that none of the vegetable marketers had access to credit and none belong to cooperative society where they can pool resources together to help their members financially. Matsane and Oyekale (2014) reported a similar result that lack of financial support militates against effective vegetable marketing. Low seasonal supply of vegetables (carrot and cucumber) which may be due to seasonal variation, perishability and deterioration in the quality of the vegetables. Finally, the low supply of vegetables due to seasonal variation was also a severe vegetable marketing constraint in the study area. There was a high supply of vegetables during the season which usually attracts low pricing while the supply is low during offseason which attracts a higher vegetable price.

\section{Conclusion}

The study focused on the marketing of vegetables (carrot and cucumber). This study revealed that vegetable marketing is a simple lucrative enterprise that does not require a huge start-up capital to establish. The marketing of vegetables had been the source of employment opportunity for many populaces, especially females who absorbed a greater percentage of the business. It provides the marketers with income needed for their wellbeing and to curb malnutrition and diseases. Vegetable marketing shows to be viable as the marketing margins of the marketers were positive with a margin of $26.30 \%$ and $20.18 \%$ for cucumber and carrot, respectively. However, there were some constraints prevalent in the study area which had impeded the realization of the potential of the business. Their major limitations were backwardness posed by the high cost of shop rent, high cost of transportation, low capital, poor agricultural pricing, finance and a low reasonable supply of vegetables due to seasonal variation. Therefore, an improvement in these constraints would enhance the performance of this business in the study area.

Attention should be given in the promotion of all vegetable marketing, carrot and cucumber in particular since it adds to the development of the economy of the country and serves as means of livelihood to many people. This could be achieved by building hygienic, modern and sufficient market stall at a low and affordable rent rate by the local, state or federal government. This would help to reduce the high rent paid by the marketers, reduce their cost of marketing and increase their share in the consumers' price. Improvement of infrastructures such as road is very important to vegetable marketers to curb the problem of high cost of transportation. This would not only reduce the time and cost of transportation but would also reduce the damage caused during distribution as a result of bad roads. The government and private sectors can invest in rural to urban, and vice versa, transportation system by making available buses that can convey people and their vegetables at a subsidized rate. Provision of available, accessible and affordable credit facilities to vegetable marketers is very important in vegetable marketing. This would go a long way to reduce the financial constraints, increase the level of investment and encourage other youths to engage in the marketing of this profitable produce. Government intervention in agricultural price system through price ceiling and price floor is needed to control the price instability in the study area. In addition, post-harvest technologies should be provided to enable the product to be available both in and off-season. This would help in reducing the price fluctuation and lead to efficient marketing of the product.

\section{References}

Ali M, Farooq U, Shih YY. 2002. Vegetable research and development in the ASEAN region: A guideline for setting priorities. In: C.G. Kuo (editor). Perspectives of ASEAN Cooperation in Vegetable Research and Development. Shanhua, Taiwan. Asian Vegetable Research and Development Centre. pp: 20-64.

Arene CJ. 2003. Introduction to Agricultural Marketing Analysis and Policy. Enugu, Nigeria: Fulladu Publishing Company.

Asogwa BC, Okwoche V. 2012. Marketing of agricultural produce among rural farm households in Nigeria: The case of sorghum marketing in Benue State, Nigeria. International Journal of Business and Social Science, 3(13): 269-277.

Botlhoko G, Oladele O. 2013. Factors affecting farmers' participation in agricultural projects in Ngaka ModiriMolema District North West Province, South Africa. Journal of Human Ecology, 41(3): 201-206.

Dinesh V, Sharma A. 2019. Marketing margin, price spread and marketing efficiency analysis on different poultry farms. International Journal of Current Microbiology and Applied Sciences, 8(6): 1039-1046.

ENADEP, 2012. Enugu State Agricultural Development Programme: Annual Report. Published by Enugu State Government of Nigeria

Fadipe AEA, Falola A, Salami MF, Okpara CC. 2015. Analysis of mango marketing in Ogbomosho, Oyo state, Nigeria. Equity Journal of Science and Technology, 3(2): 76-83.

Firdaus M, Gunawan I. 2012. Integration among regional vegetable markets in Indonesia. Journal of International Society for Southeast Asian Agricultural Sciences, 18(2): 96-106.

Kotler P, Keller K. 2012. Marketing Management (14th ed.). New Jersey, United States of America: Pearson Prentice Hall.

Matsane S, Oyekale A. 2014. Factors affecting marketing of vegetables among small scale farmers in Mahikeng local Municipality, North West Province, South Africa. Mediterranean Journal of Social Sciences, 5(20): 390-397.

National Population Commission 2006. 2006 Population and Housing Census of the Federal Republic of Nigeria, Abuja. Vol. 1 pp: 67-76.

Obetta AE, Achike AI, Mukaila R, Taru B. 2020. Economic analysis of marketing margin of banana and plantain in Enugu State, Nigeria. African Journal of Agriculture and Food Science, 3(4): 52-62

Senyolo G, Chaminuka P, Makhura M, Belete A. 2009. Patterns of access and utilization of output markets by emerging farmers in South Africa: Factor analysis approach. African Journal of Agricultural Research, 4(3): 208-214.

Xaba B, Masuku M. 2012. Factors Affecting the Choice of Marketing Channel by Vegetable Farmers in Swaziland. Sustainable Agricultural Research, 2(1): 112-123 doi: 10.55 39/sar.v2nlp112

Yohanes M. 2015. Performance and Challenges of Vegetable Market: The Case of Kombolcha District, East Hararghe Zone, Oromia National Regional State, Ethiopia. M.Sc Thesis, Department of Agricultural Economics and Agribusiness, Haramaya University, Dire Dawa, Ethiopia. 